\title{
Richard Thelwell, Chris Harwod and Lain Greenless eds. The Psychology of Sports Coaching: Research and Practice (スポーツコーチング心理学一研究と実践)
}

\author{
雨宮 怜 ${ }^{1)}$ 夏原 隆之 ${ }^{2)}$ 市村 操- ${ }^{11}$
}

AMEMIYA Rei ${ }^{1}$, NATSUHARA Takayuki ${ }^{2}$ and ICHIMURA Soichi ${ }^{1}$

\section{1. 構成と概要}

近年, 日本のスポーツコーチング界において, コーチング推進コンソーシアムによる「グッドコ ーチに向けた『7つの提言』」(文部科学省コーチ ング推進コンソーシアム，2015）や日本体育協会 （2016）によるコーチ育成「モデル・コア・カリ キュラム」が作成・導入されるなど, 未来に向け

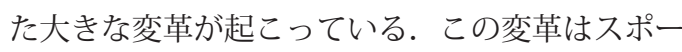
ツ指導者によるハラスメントや暴力事件など，日 本スポーツ界における指導者と選手間の問題発生 を背景として, 選手だけではなく, 指導者育成に 対する必要性が高まったことに起因していると考 えられる（文部科学省コーチング推進コンソーシ アム，2015)。しかしながら，そのような取り組み は, 未だ日本スポーツ界に㧈いては十分ではない.

日本のスポーツ界が出遅れる中, すでに海外に おいては，スポーツコーチング領域の発展を目的 として, スポーツ心理学や心理学における最新理 論や実践法がスポーツ現場に導入されている。そ のため, 日本のスポーツコーチング界においても, スポーツ心理学や心理学の理論および実践をコー チングに活用するための知識や技術の普及が求め られる. 本書評で取りあげる "The Psychology of Sports Coaching: Research and Practice（スポーツコ ーチング心理学：研究と実践）"は, スポーツコ ーチング心理学の著名な研究者ならびに実践家に よって執筆された, 近年のスポーツコーチング心 理学における研究を総合的にレビューした最初の
著書である. 本著では, 初学者から研究者, また 実践家まで, 多くの人々にとって有益なスポーツ コーチングに寄与する情報や知見が示されてい る. 章立ての概要を以下に示す.

第 1 部 コーチングの環境に影響をあたえる要因 1.コーチングのキャリア移行, 2. 青少年競技者 のための望ましい影響の創造, 3. 効果的なコー チングにおける背景理論 (自己決定理論), 4. コ 一チ・競技者間の人間関係, 5. 組織の変化とコ 一チの引継ぎ, 6. コーチと親の関係.

第 2 部 コーチのパフォーマンスの向上

7. コーチの心理的欲求の充足, 8. ハイ・パフォ ーマンス・コーチング, 9. コーチのストレスと その影響, 10. コーチの競技者への期待とその影 響, 11. 有効なコーチングとは何か, 12. コーチ の心理的健康.

第 3 部 コーチとして働くこと

13. 変革型リーダーシップとコーチの役割, 14 . 競技者の精神的成長に有効なコーチ能力, 15. 効 果的なコーチのコミュニケーション，16. リジリ エンスを高めるコーチング, 17 . 意思決定をトレ 一ニングに組み入れること，18. 社会的アイデン ティティの役割.

本書評では, 日本のスポーツやスポーツコーチ ング, またスポーツ心理学の専門家や実践家に対 する情報提供を目的として, 本著について上記の 3 パート合計 18 章のうち, 重要と思われる6つ
1）筑波大学体育系
干 305-8574 茨城県つくば市天王台 1-1-1
2) 東京成徳大学応用心理学部
干 276-0013 千葉県八千代市保品 2014
連絡先 雨宮 怜
1. Faculty of Health and Sport Sciences, University of Tsukuba 1-1-1, Tennodai, Tsukuba, Ibaraki 305-8574
2. Faculty of Applied Psychology, Tokyo Seitoku University 2014 Hoshina, Yachiyo, Chiba 276-0013
Corresponding author amemiya.rei.km@u.tsukuba.ac.jp 
の章について，概要を紹介し，本書の日本のスポ ーツコーチングに資する点について論評する.

2. Chap. 3. The theory (SDT) behind effective coaching : 効果的なコーチングにおける背 景理論（自己決定理論）

本章では，自己決定理論の枠組みからスポーツ コーチングの研究を概観し，コーチが自律支援的 なコーチングスタイルの採用を試みる際に経験す る課題や障壁について紹介されている.

コーチが行うアスリートへの自律への支援や構 造，関与の程度がアスリートの心理的満足度やモ チベーションに影響を与えるものの, 当該支援行 動に関するコーチ自体の理解不足や自律支援的な 行動に対する他者からの誤解（放任主義的）など によって，制御的スタイルが採用されてしまうこ とがあるという。しかしながら近年，自律支援的 なコーチング行動の効果が報告されるようにな り，世界的なトップチームの成功に貢献したこと が報告されている。 また，ロンドンパラリンピッ ク競技大会のコーチが自律支援型戦略の使用を促 す介入を実施したところ，メダル数や仕事への満 足度などへの効果が確認され，自律支援型コーチ ングスタイルの有効性が認められている.

そのため，アスリートやコーチが心理的な成長 や幸福感，優れたパフォーマンスを実現するため に，自律支援型のコーチングスタイルへの転換が 推奨されている．今後，自律支援的な行動をとる 際の障壁や問題点へのより多くの理解に加えて, コーチ自身の性格的特徵や対人関係スタイル，対 象となるアスリートへの理解，文脈などに合わせ たコーチングの実施や，選手やマネージャーなど の周囲に対しても当該指導スタイルに関する教育 が求められていることが言及されている.

\section{Chap. 4. Understanding and enhancing} coach-athlete relationships through the $3+1$ Cs model : コーチ・競技者間の人間関係の

\section{3+1 Cs モデルによる理解と向上}

本章では，コーチと競技者の関係はスポーツ という社会的状況における双方向的な関係にあ
り，その関係は感情（Closeness: 親密さ），思考 (Commitment: 関与), 行動 (Complementarity: 相 補性）の3つの面（3C）を有すること，また 後に目標の共有（Co-orientation）が追加され, 3+1Cs モデルとなったことが紹介されている.

$3 \mathrm{C}$ を測定する質問紙が本章の第二著者らによ って開発され（Jowett and Ntoumanis, 2004)，人間 関係を良好にする前提条件と，良好な人間関係が 競技成績や競技者の幸福感におよぼす影響などの 研究が広く行われるようになったという。良好な 人間関係の前提条件としてはコーチ個人のパーソ ナリティや，コーチングへの情熱，リーダーシッ プの型や，コーチのキャリアなどが研究されてお り, 調和的情熱と強迫的情熱の人間関係におよぼ す研究では，自律性を伴う調和的情熱で指導して いるコーチは選手との人間関係が良いことが示さ れている。ささらに，良好な人間関係のスポーツ行 動への影響に関しては，過去 15 年ほどの間に多 くの研究が発表され，その影響は，選手個人の練 習や試合での満足感，主観的幸福感，メンタルヘ ルスの予防や，チームとしての凝集性，効力感， 社会的受容などとの関連が報告されている.

しかし，上記の研究のほとんどが相関関係によ って結論を導いており, 介入実験の方法は少数し か用いられていないという。そのため今後は，人 間関係を良くする介入が行われ，その結果の満足 感の変化を確かめるような因果関係を求める研究 の必要性が指摘されている.

\section{Chap. 8. High performance coaching:} Demands and development：ハイ・パフォ ーマンス・コーチング一要求と育成一

本章では，コーチをパフォーマーという観点か ら捉えている. 彼らの実践に役立つ基礎的知識の 検討と発展に加え，そのような知識を普及するた めのコーチ教育システムなどの組織的構造の構築 について紹介されている.

本章ではまず, コーチに必要な予備知識として, 技能や戦術やトレーニング法などの「専門知識」 に加えて, チーム内外の他者との交流や，パフォ ーマンス・競技の成果に繋げるための「対人関係 
知識」, および, コーチ自身の内面の状態を反省 的に省察する「個人内知識」が説明されている. さらに, 優れたコーチは必然的に学習者であるべ きであり, 彼らが行う学習を「フォーマル」「イ ンフォーマル」「ノンフォーマル」の3つに類型 化することができると紹介されている. そして, いわゆる「インフォーマル」な学習であるアスリ ート経験が有利に働くことがある一方，エリート 選手であっても，コーチとして成功するとは限ら ないことや，実際の現場での指導経験量だけでは 能力を評価することはできず, 経験の質の重要性 が指摘されている.

本章のテーマに基づいた今後の示唆として, 雇 用の問題や早期離職によって多くのコーチのキャ リアが失われてしまうため, コーチを雇用する組 織において個人の組織適合性を考慮した評価や根 拠に基づいた採用を行う必要性が指摘されてい るまたた組織がコーチの継続的な発達を実現する 社会的かつ物理的な環境を構築する必要があると ともに, コーチ自身が実践や地位を向上させる必 要もあり, 生涯学習の価值づけや, 自身の学習に 投資する重要性が説明されている.

\section{Chap. 9. Coach stress and associated impacts : コーチのストレスとその影響}

この章では, コーチは競技者とは異なり, チー ムや競技会のマネジメントなど多面的な役割を担 っており, 経験するストレスも競技者とは異なる ことから, 独自のストレス研究が必要であること が指摘されている.

コーチ独自のストレス問題として，バーンアウ トやコーチの仕事からの辞職の問題が大きく取り 上げられている．この章の筆頭著者は 2012 年ロ ンドン・オリンピックに向けた英国のエリート・ コーチ育成プロジェクトの中で, オリンピック・ コーチのストレス研究を担当していたが，本章で はそのようなエリート・コーチだけではなく, 高 校や大学のレベルの教師兼コーチのストレス研究 も紹介されている.

コーチに特有なストレッサーとしては資金問 題, 練習場の確保, 親競技団体との不和などがあ
げられている. そして, ストレッサーによって生 起するストレス反応は, コーチだけではなく競技 者にも影響を与えることなどが指摘されている. また, ストレスの影響を受けやすい条件としては, 特性不安が高いという個人内条件だけではなく, 過剩な仕事量や自律性の制限や社会的サポートの 無さなどが挙げられている。 そのようなストレス への対処法に関する研究は, 現在コーチが自分で 実行している方法の調査とともに, 経験のあるコ ーチの助言が集められるなどがある.

コーチがバーンアウトに陥らないための心理技 法訓練のプログラムも, 近年, 開発され実施され るようになってきている. 将来はこのようなプロ グラムの開発と効果の実証的研究が必要である. それと同時に, コーチをバーンアウトから守る社 会サポートの必要性も示唆されている.

\section{Chap. 13. Transformational leadership and the role of the coach : 変革型リーダーシッ プとコーチの役割}

スポーツコーチングにおける最近の発展の 1 つ は, 変革型リーダーシップ理論の導入である. 本 章ではスポーツコーチング場面でのリーダーシッ プとして, 変革型リーダーシップ理論について論 じられている.

変靯型リーダーシップとはフォロアーの感情面 に働きかけることで動機づけを高め, フォロアー 自身が期待していた以上の成果を達成させるよう なリーダーシップである。一方, 賞罰を用いてフ オロアーの行動を動機づける方法は取引型リーダ ーシップと呼ばれ, 変靴リーダーシップは取引 型リーダーシップに取って代わるものではなく, 双方が相まって効果を発揮するものであると考え られている.

変革型リーダーシップは, フォロアーのリーダ 一に対する信頼と忠誠心を生夕出すようなリーダ 一の行動や態度を特徴としている。一方で, その ような行動と態度とは具体的にどのようなもので あるか, どのように測定するかについては様々 な議論がなされてきた. 現在, 変革型リーダー シップ理論に関しては, ビジネス, 軍隊, 教育 
など様々な領域におけるリーダーの行動を測定 するための質問紙（Differentiated Transformational Leadership Inventory: DTLI）が開発されている. この DTLI は変革型リーダーシップを構成する, 鼓舞的動機づけ，良い手本の役割，チームの目標 の合意とチームワークの育成, ハイ・パフォーマ ンスへの期待，知的な刺激を与えること，一人一 人への配慮, 結果への報酬の 7 つの下位次元を測 定している.

変革型リーダーシップの有効性は様々な領域で 証明されている。スポーツにおいて変革型リーダ ーシップ行動は, 競技者の内発的動機づけ，ウエ ルビーイング, 欲求充足, 努力発揮, チームの凝 集性とチームのための自己犠牲など様々な心理 的・行動的側面にポジティブな影響を与えている ことが報告されている. 今後は, ストレス対処法, 成功・失敗の原因帰属，メンタル・タフネス等と の関係についても，質問紙調査や客観的な行動測 定を通じて検討することが課題である.

\section{Chap. 16. Developing resilience through coaching : リジリエンスを高めるコーチン グ}

スポーツにおいて不利な状況に耐えて挽回する 能力をリジリエンスと捉え，アスリート個人だけ でなくチームのリジリエンスを対象とした研究も 始まっている，本章は，スポーツにおいてリジリ エンスを高めるコーチング法の発展と今後の展望 について論じている.

アスリートは練習や試合に打いて多くの試練に 晒され，強いストレスを感じている．そのような スポーツ環境下に扑いて, 人間関係やコーチの建 設的な行動は，アスリートが試練を克服すること を助け，失敗を乗り越えるように勇気づけること に寄与していた。これは, ユーススポーツがリジ リエンスを育てるための適切な手段であるという 考えを支持するものであり，将来のコーチングの 実践に有意義な情報をもたらしている.

チームのリジリエンスには, 変靯型リーダーシ ップ，チーム内でのリーダーシップの分担，チー ムでの学習, 社会的アイデンティティ, ポジティ
ブ感情といった心理的要因が影響していることが 示されている.エリート・スポーツ・チームでは, こうした要因に支えられることによって，競技者 はストレスフルな状況に直面した際のリジリエン スを認知・感情・合理的判断の面で発揮し続けた と考えられている.

スポーツにおいてコーチングを通したリジリエ ンス育成の実証的研究はこれからの課題である が，組織心理学における先行研究を参照して進め られることが期待される．なお，研究の詳細につ いては，原著を参照されたい。

\section{8. 問題提起}

以上，本著における 6 つの章の概要を紹介し た. 最後に, 日本のスポーツコーチング研究に関 する問題提起と，その問題に対する本著の役割を 述べたい.

これまで日本のスポーツコーチング研究では, 運動動作やゲーム分析など，テクニカルな側面に 焦点を当てた検討が多く行われてきた.そのため, いわゆる人（コーチ）と人（アスリート）の関係, 人（コーチ）が人（アスリート）を教えるという 心理学的な側面や教育的側面, 社会的側面に関す る知見が, 十分に検討されてこなかった。

またスポーツ心理学においても,コーチや選手, チームに向けたアプローチは, 運動学習や動機づ け理論、メンタルトレーニングなどを通した競技 力向上や情報提供に力点が置かれていた（e.g., 遠 藤，2017)。そのため，これまではアスリートや チームに向けてスポーツメンタルトレーニングを 実践する者は，独学でコーチ - 選手間の関係性に ついて理解する必要があり, 近年ようやく, コー チ - 選手の人間関係やコミュニケーションの重 要性が議論されるようになってきた（e.g., 荒井, 2019 ；市村ほか，2019）。すなわち，これまでの スポーツコーチング学やスポーツ心理学の領域に おいては，人と人との関係や選手を指導するコー チ自身に対する情報が希薄になっていたと言って も過言ではないだろう。そのようなスポーツ界に おけるコーチングの人間学的知見が，本書によっ てカバーされ始めたと言える. 
本著では, コーチの心理や彼らが直面する心理 社会的問題について, 詳細な説明がなされてい る，競技活動を通したストレスは，選手だけでは なくコーチにも生じ, それがアスリートにも影響 する. そのため, アスリートの健康維持やパフォ ーマンスを最大化するためには, コーチをパフォ ーマー (実行者) としてとらえ，支援することが 不可欠である. 本著は, コーチ自身やアスリート， そして彼らの支援者や周囲の人々に対して新たな 視座を提供するものであり, 本著を通してアスリ ートだけではなくコーチ, そしてコーチ - 選手関 係についての研究や教育, 支援が, 日本スポーツ 界で活性化することが期待される.

\section{文 献}

荒井弘和（2019）コーチのコミュニケーション. 平野裕 一ほか編, グッドコーチになるためのココロエ。培風 館, pp.44-52.

遠藤俊郎（2017）心的・知的能力のトレーニング. 日本 コーチング学会編, コーチング学への招待. 大修館書 店, pp.183-197.
市村操一・川北準人・岡田弘隆・山口香・木幡日出男(2019) コーチ・競技者間の人間関係の心理学的研究の展望一 CART-Qを用いた研究を中心に一. コーチング学研究, $33: 13-20$.

Jowett, S., and Ntoumanis, N. (2004) The coach-athlete relationship questionnaire (CART-Q): Development and initial validation. Scandinavian Journal of Medicine \& Science in Sports, 14(4), 245-257.

文部科学省コーチング推進コンソーシアム（2015） グッドコーチに向けた「7つの提言」新しい時代 にふさわしいコーチングの確立に向けて. https:// www.mext.go.jp/b_menu/houdou/27/03/_icsFiles/ afieldfile/2015/03/13/1355873_3.pdf, (参照日 2020 年 5 月3日).

日本体育協会（2016）平成 27 年度コーチ育成のため の「モデル・コア・カリキュラム」作成事業報告書. https://www.japan-sports.or.jp/Portals/0/data/ikusei/doc/ curriculum/modelcore.pdf, (参照日 2020 年 6 月 29 日).

$$
\left(\begin{array}{l}
2020 \text { 年 } 5 \text { 月 } 25 \text { 日受付 } \\
2020 \text { 年 } 7 \text { 月 } 21 \text { 日受理 }
\end{array}\right)
$$

Advance Publication by J-STAGE

Published online 2020/8/13 